\title{
The Life-History and Bionomics of the Apple Rust Mite Calepitrimerus baileyi (Acari: Eriophyidae)
}

\author{
B. A. Abou-Awad ${ }^{*}$, S. I. Afia* and M. M. Al-Azzazy ${ }^{* *}$ \\ "Plant Protection Dept., National ResearchCenter, Dokki, Cairo, Egypt \\ ** Dept. of Agric. Zoology and Nematology, Fac. Agric., Al-Azhar Univ., Cairo, Egypt
}

\begin{abstract}
Ecological studies on the apple rust mite Calepitrimerus baileyi Keifer was conducted for one year in an abandoned Anna apple orchard in Egypt. Population dynamic of the eriophyid apple prey was affected by climatic conditions. and vertical distribution, and about 11 generations were recorded whole year. Leaves at middle levels of apple cultivar were found preferable to the mite feeding than those at the top and bottom. C. baileyi successfully developed to adult stage when reared on leaf discs from soft lateral apple branches. At 16 and $37^{\circ} \mathrm{C}$, the adults began to slow down activity and then died. It was able to develop at temperature between $23-35^{\circ} \mathrm{C}$ and $65 \%$ R. H. Adult life cycle and longevity decreased with increasing temperature. Fecundity was highest at $35^{\circ} \mathrm{C}$ and averaged 23 eggs per female. Life table parameters showed that the intrinsic rate of natural increase (rm) increased with temperature increase to a maximum of 0.158 at $35^{\circ} \mathrm{C}$. Population of $\mathrm{C}$. baileyi multiplied 15.94 times in a generation time $\mathrm{f} 17.47$ days at $35^{\circ} \mathrm{C}$ and recorded 8.79 times in a generation time of 25.8 days at $23^{\circ} \mathrm{C}$ under laboratory conditions.
\end{abstract}

Key Words: Ecology, Biology, Calepitrimerus baileyi, Acari, Eriophyidae.

\section{INTRODUCTION}

The apple rust mite, or Bailey's rust mite, Calepitrimerus baileyi Keifer was firstly reported by Keifer (1938) on apple leaves in California and South Dakota (Jeppson et al., 1975). Mite feeding caused browning on the underside of apple leaves, partial defoliation, russet on fruit and delayed or inhibited apical growth.

In Egypt, C. baileyi reached damaging levels in many apple orchards, particularly on Anna apple cultivar. No work has been done before on the biology and ecology of this harmful pest. This study presents information on the seasonal trend, behaviour of C. baileyi and its life history.

\section{MATERIALS AND METHODS}

\section{Ecological Studies:}

Ecological studies on C. baileyi and its predator, Typhlodromus pyri chueten were carried out in an abandoned apple orchard (Malus domestica Borb.), seven-years old, Giza, for one year (April 2009 to March 2010). Ten apple trees from Anna cultivar of similar size, vigor and shape were selected. Samples of 25 leaves were taken at random weakly to estimate the eriophyid and phytoseiid mite populations.

To study the comparative abundance of C. baileyi and its vertical distribution, 60 leaves were collected randomly from the top, bottom and middle of Anna cultivar. Sampling was conducted on the $15^{\text {th }}$ of every month. Leaves of Anna apple trees from the upper branches $(50-70 \mathrm{~cm})$, represented the top-level leaves, while those on the branches of the trees up to a height of $100-120 \mathrm{~cm}$ above ground level, represented the bottom-level leaves. The foliage between the top and the bottom levels was regarded as middle-level leaves.

To determine the number of annual generations of $C$. baileyi under environmental conditions, the percentage of immature stages was estimated weekly. Period at which the highest percentage of the immature stages occurred represented a generation.

\section{Biological Studies:}

Mites were reared on leaf discs, $2 \mathrm{~cm}$ diameter containing a part of midrib, taken from leaves of soft lateral apple branches. The discs were placed ventral side up on moist filter paper. Thirty newly mated females of $C$. baileyi were obtained from infested apple leaves, and placed singly on the leaf discs. Each female was allowed to deposit one egg. Leaf discs were placed in incubators at different constant temperatures (16. 23, 29, 35 and $37^{\circ} \mathrm{C}$ ) and $65 \%$ relative humidity and a photoperiod $12 / 12 \mathrm{~h}$ light/dark. Development of mites was observed twice daily. Insemination took place soon after male and female emergence, each newly virgin female was transferred for $24 \mathrm{~h}$ to a leaf disc previously inhabited by an adult emerged male, to allow insemination by spermatophores, then females and males were transferred back to their previous substrates. Life table parameters were calculated according to a Basic computer program (Hulting et al., 1999). 


\section{RESULTS AND DISCUSSION}

\section{Seasonal Variations:}

The population dynamics of C. baileyi and its predatory phytoseiid mite $T$. pyri for a one year study on the apple trees (cv. Anna) and weather records are presented in Fig. 1. In 2009, C. baileyi first appeared on apple trees during the first week of April when new Anna apple leaves protruded from the buds. The numbers of mites fluctuated rose in matted hairs of the lower surface of the leaves until the second week of July. The population fluctuation continued at a semi high or moderate levels until the second week of September and then fluctuated with moderate or low levels during October and November. Climatic conditions, the occurrence in matted hairs of the lower leaf surfaces, vertical distribution and prevailing natural enemy may have a role to play.

It is of interest to note that during development, $C$. baileyi displayed deuterogyny which is the occurrence of two types of females, primary and secondry (Keifer, 1942; Jeppson et al, 1975 and Manson, 1984). The primary female or protogyne has a male counterpart and the ventral of both sexes have microtubercles. The secondry female or deutogyne lacks ventral microtubercles, and has no male counterpart. In early April at the beginning of the growing season, the deutogynes started egg-laying. The new progeny or protogynes were commonly found on the leaves from early April until the end of November. At about mid August, a considerable population consisting of eggs, nymphs, protogynes, deutogynes and males was found on the leaves. At early September, deutogynes of $C$. baileyi hibernated in their quarters with rare numbers, mainly in small permanently dormant buds and under loose bark of spurs and around buds on 1-year old shoots, and moved into fruit buds between the bud burst and pink bud stages and into vegetative buds as the buds began to swell.

Three annual peaks of seasonal abundance on Anna apple cultivar were recorded. The highest populations occurred in the third week of June and the second week of both July and August of the study year, averaging $43.8,57.9$ and 42.4 mite individuals per leaf at average temperature 29,30 and $28{ }^{\circ} \mathrm{C}$ and $50 \%, 75 \%$ and $60 \%$ R.H., respectively (Fig. 1). Highly significant positive correlation (0.858) was noted between mite population and temperature. Significant positive correlation $(0.150)$ also occurred between mite population and relative humidity. It could be concluded that the population responded to high temperature degrees. Injury of apple orchards caused by $C$. baileyi became noticeable early in mid June. The lower surface of the leaves turned brown or bronzed, while the upper surfaces remained nearly green, which suggests that the mites feed mainly on the lower surfaces of the leaves.

About 11 generations of $C$. baileyi were recorded on apple leaves during the study period. The longest generation for $C$. baileyi was that, which passed throughout fall months and lasted for about five weeks, while the shortest generation occurred in summer and lasted for about two weeks (Fig. 2). This confirms again that the changeable environmental factors had a great effect on the apple rust mite. The severe damage occurred in summer.

The numerical changes in vertical distribution of the mite C. baileyi on Anna apple trees for one year, with temperatures and relative humidities for the corresponding periods are given in Fig. 3. Tracing the population trend at top and middle revealed that its peak mostly occurred during July, then declined till November. Its density exhibited a gradually increase and decrease throughout summer and fall and still remained at a noxious level during summer. At the middle level, leaves of Anna apples had significantly more numbers of mite species in comparison to the top and bottom levels. The data suggest that the middle leaves were preferable to the mite and are useful for sampling of the apple rust mite population to evolve suitable strategies for the application of chemical control.

\section{Predacious Mite:}

In nature, acarine pests are only a part of biological complex of which predacious mites, particularly phytoseiids group, could be of value in checking infestations. The population dynamics of phytoseiid predator $T$. pyri Schueten was studied during a whole year (2009-2010). It was relatively numerous on Anna apple cultivar associated with the apple rust mite C. baileyi. Population density started to appear in May then increased and fluctuated till reached two peaks in September and October, then tailed off in November. The predator population positively correlated with that of $C$. baileyi. Its density averaged from 0 to 0.6 individual/leaf (Fig. 1). This may indicate that the eriophyid prey probably play an important part as a prey for the predator.

\section{Biology:}

The present study was conducted to determine the effect of different constant temperatures on the developmental duration of different stages, adult longevity and fecundity of protogynes $C$. baileyi. At 16 and $7 \mathrm{C}$ the adult began to cease its activity, then died. Abou-Awad et al. (2010) stated that below $20^{\circ} \mathrm{C}$ the activity of the peach silver mite Aculus fockeui (Nalepa and Trouessart) was ceased, whereas at $36^{\circ} \mathrm{C}$ the new virgin adults died. 


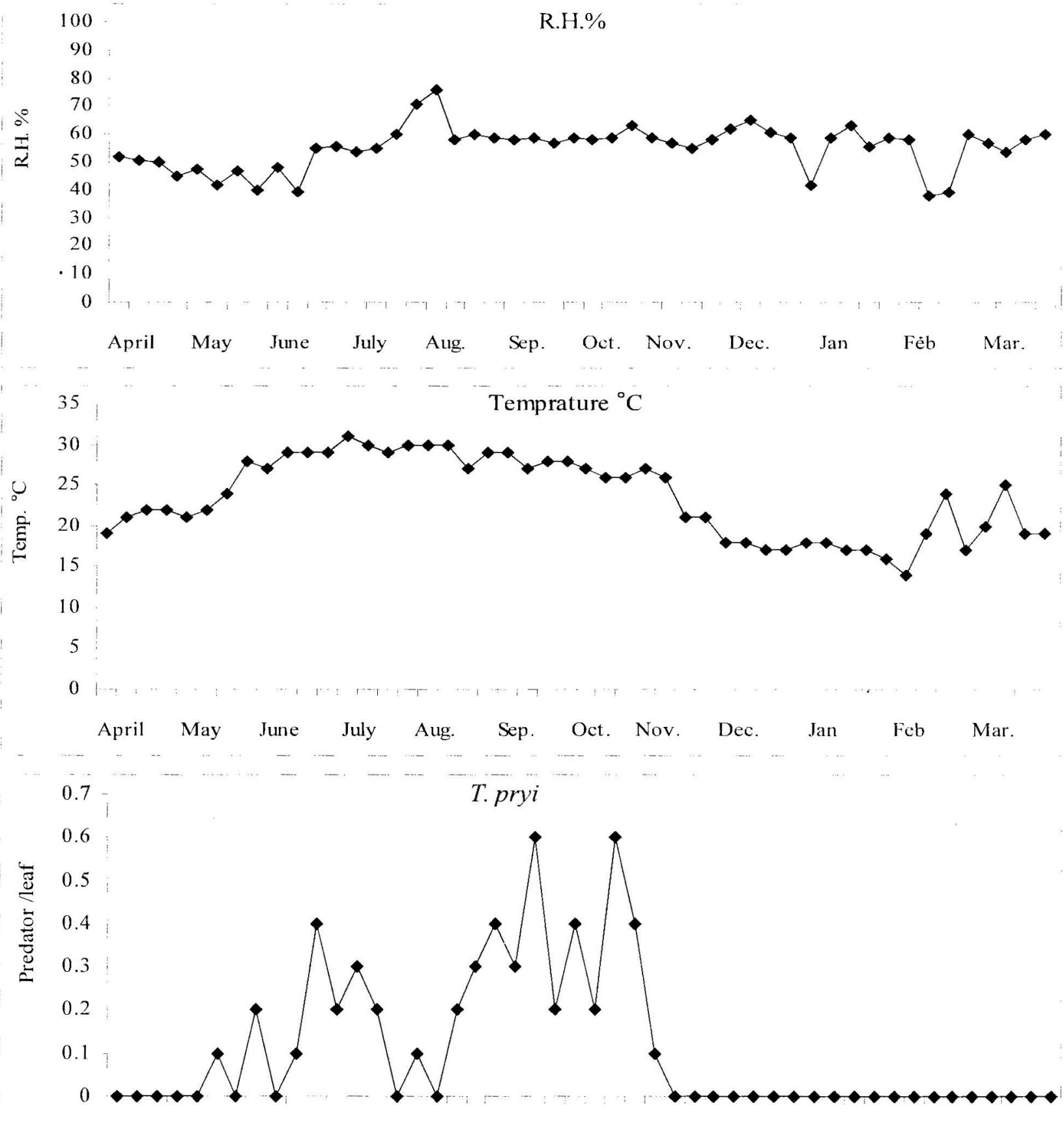

April May June July Aug. Sep. Oct. Nov. Dec. Jan Feb Mar.

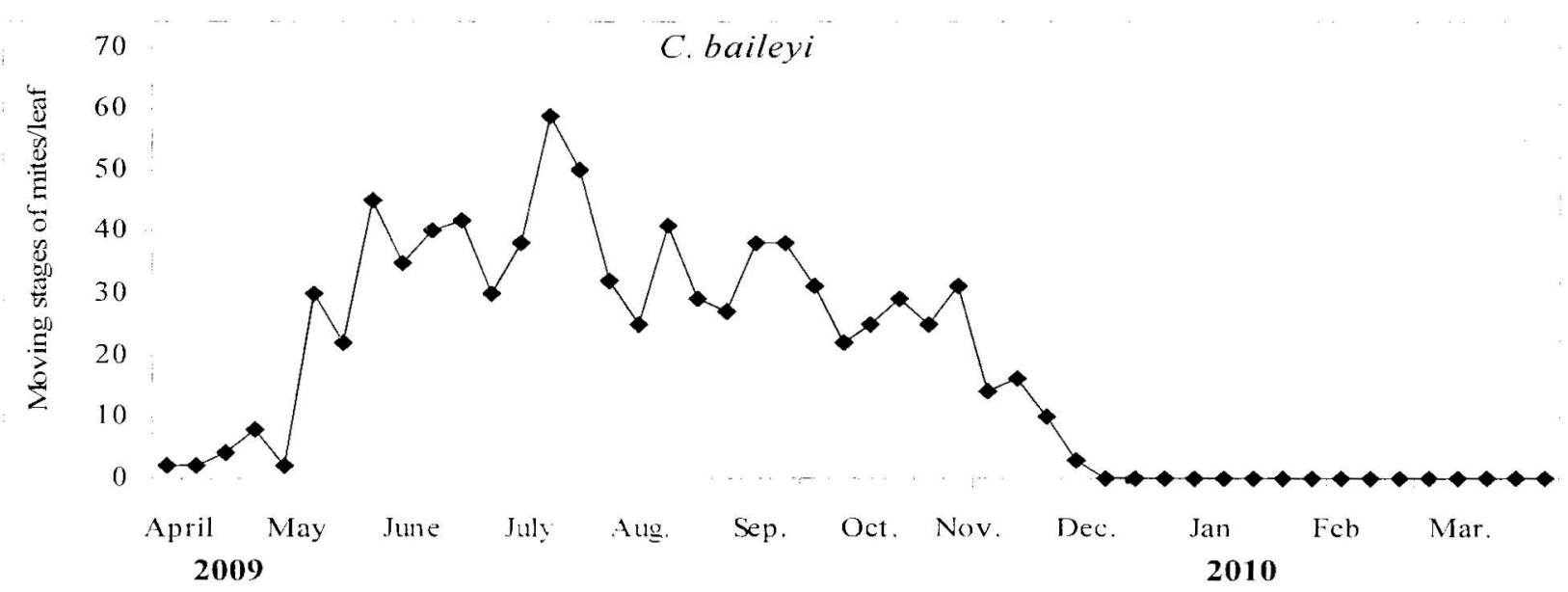

Fig. (1): Population density of the apple rust mite. C. haileyi and its phytoseiid predator on Anna apple leaves in abandoned orchard from Anril 2009 to March 2010 and weather records. 


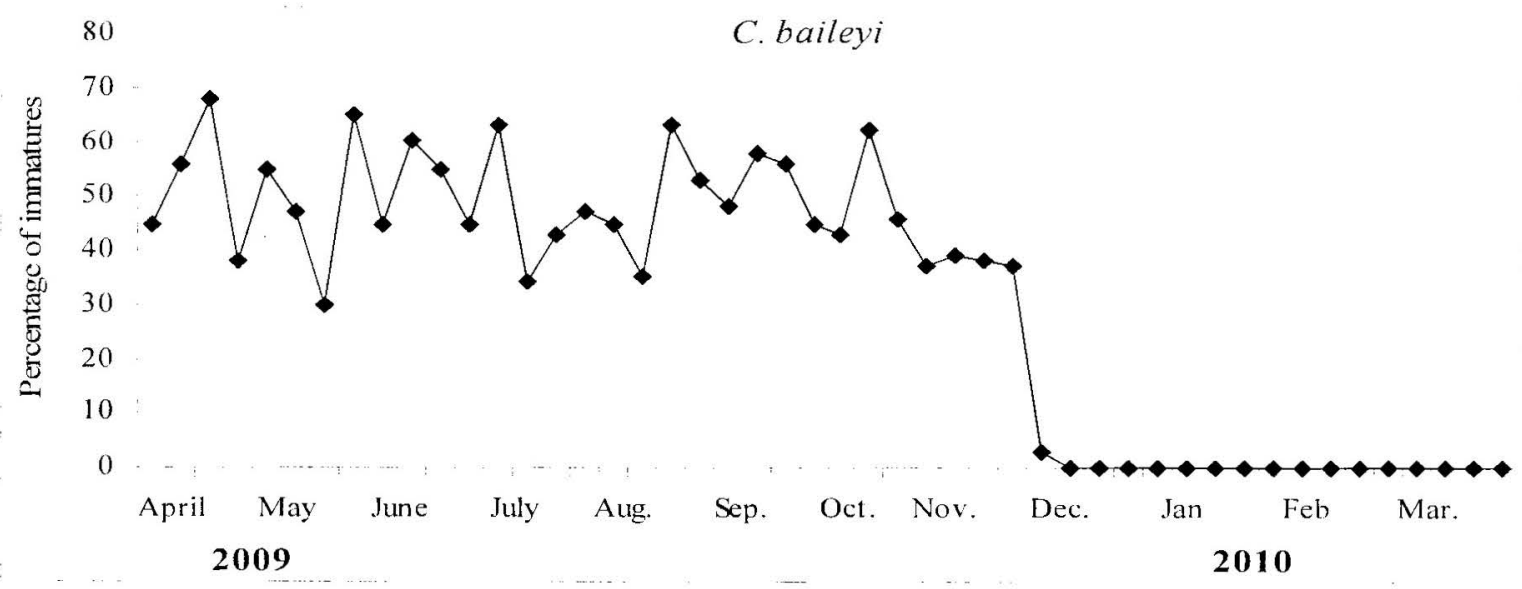

Fig. (2): Percentage of immature stages in the total population of the apple rust mite, C. baileyi on Anna apple leaves in abandoned orchard from April 2009 to March 2010.

Table (1): Developmental periods of different stages in days and fecundity rate of C. baileyi reared on leaf apple discs at different temperatures and $65 \%$ R.H

\begin{tabular}{lllll}
\hline \multicolumn{1}{c}{ Mite stage and fecundity } & \multicolumn{1}{c}{ Sex } & $23^{\circ} \mathrm{C}$ & $29^{\circ} \mathrm{C}$ & $35^{\circ} \mathrm{C}$ \\
\hline Egg & Female & $5.30 \pm 0.16$ & $3.61 \pm 0.17$ & $2.90 \pm 0.15$ \\
& Male & $5.10 \pm 0.11$ & $3.36 \pm 0.12$ & $2.80 \pm 0.21$ \\
\hline First instar nymph & Female & $2.08 \pm 0.20$ & $1.84 \pm 0.16$ & $1.18 \pm 0.09$ \\
& Male & $2.00 \pm 0.17$ & $1.90 \pm 0.18$ & $1.09 \pm 0.11$ \\
\hline Nymphochrysalis & Female & $0.31 \pm 0.04$ & $0.24 \pm 0.09$ & $0.19 \pm 0.04$ \\
& Male & $0.31 \pm 0.06$ & $0.24 \pm 0.04$ & $0.19 \pm 0.02$ \\
\hline Second instar nymph & Female & $1.75 \pm 0.14$ & $1.69 \pm 0.13$ & $1.00 \pm 0.02$ \\
& Male & $1.90 \pm 0.16$ & $1.81 \pm 0.24$ & $1.09 \pm 0.09$ \\
\hline Imagochrysalis & Female & $0.27 \pm 0.06$ & $0.21 \pm 0.04$ & $0.17 \pm 0.08$ \\
& Male & $0.29 \pm 0.09$ & $0.21 \pm 0.06$ & $0.17 \pm 0.04$ \\
\hline Total & Female & $9.71 \pm 0.34 \mathrm{a}$ & $7.59 \pm 0.32 \mathrm{~b}$ & $5.44 \pm 0.18 \mathrm{c}$ \\
& Male & $9.60 \pm 0.32$ & $7.52 \pm 0.17$ & $5.34 \pm 0.22$ \\
\hline Pre-oviposition & Female & $4.50 \pm 0.17$ & $3.07 \pm 0.14$ & $1.27 \pm 0.12$ \\
\hline Generation & Female & $14.21 \pm 0.54 \mathrm{a}$ & $10.66 \pm 0.63 \mathrm{~b}$ & $6.71 \pm 0.42 \mathrm{c}$ \\
\hline Oviposition & Female & $24.08 \pm 0.82 \mathrm{a}$ & $22.00 \pm 0.77 \mathrm{a}$ & $21.81 \pm 1.21 \mathrm{a}$ \\
\hline Total fecundity & Female & 12.50 & 19.70 & 23.09 \\
\hline Post-oviposition & Female & $6.33 \pm 0.37$ & $4.76 \pm 0.42$ & $2.45 \pm 0.33$ \\
\hline Longevity & Female & $34.91 \pm 1.21 \mathrm{a}$ & $29.83 \pm 1.11 \mathrm{~b}$ & $25.53 \pm 1.53 \mathrm{c}$ \\
& Male & $32.60 \pm 1.44 \mathrm{a}$ & $28.18 \pm 0.97 \mathrm{~b}$ & $23.60 \pm 1.04 \mathrm{c}$ \\
\hline Life span & Female & $44.62 \pm 1.27 \mathrm{a}$ & $37.42 \pm 2.09 \mathrm{~b}$ & $30.97 \pm 1.13 \mathrm{c}$ \\
\hline & Male & $42.22 \pm 1.84 \mathrm{a}$ & $35.70 \pm 1.94 \mathrm{~b}$ & $28.99 \pm 2.12 \mathrm{c}$ \\
\hline Surviving \% & Female & 100 & 100 & 100 \\
& Male & 100 & 100 & 100 \\
\hline Number of observations & Female & 20 & 21 & 22 \\
\hline & Male & 10 & 9 & 8 \\
\hline
\end{tabular}

Means marked with the same letters in a horizontal column are not significantly different $(\mathrm{F}$-test, $\mathrm{P}<0.05, \mathrm{P}<0.01)$

Table (2): Life table parameters of C. baileyi at different temperature degrees and $65 \%$ R.H.

\begin{tabular}{lccc}
\hline \multicolumn{1}{c}{ Parameters } & $23^{\circ} \mathrm{C}$ & $29^{\circ} \mathrm{C}$ & $35^{\circ} \mathrm{C}$ \\
\hline Net reproduction rate (Ro) & 8.79 & 13.92 & 15.94 \\
Mean generation time (T) & 25.8 & 21.87 & 17.47 \\
Intrinsic rate of increase $(\mathrm{rm})$ & 0.087 & 0.120 & 0.158 \\
Finite rate of increase $\left(\mathrm{e}^{\mathrm{rm}}\right)$ & 1.059 & 1.127 & 1.171 \\
$50 \%$ mortality (in days) & 45 & 38 & 32 \\
Sex ratio (Female/total) & $20 / 30$ & $21 / 30$ & $22 / 30$ \\
Sex ratio (Female/male) & $2.00: 1$ & $2.3: 1$ & $2.7: 1$ \\
\hline
\end{tabular}




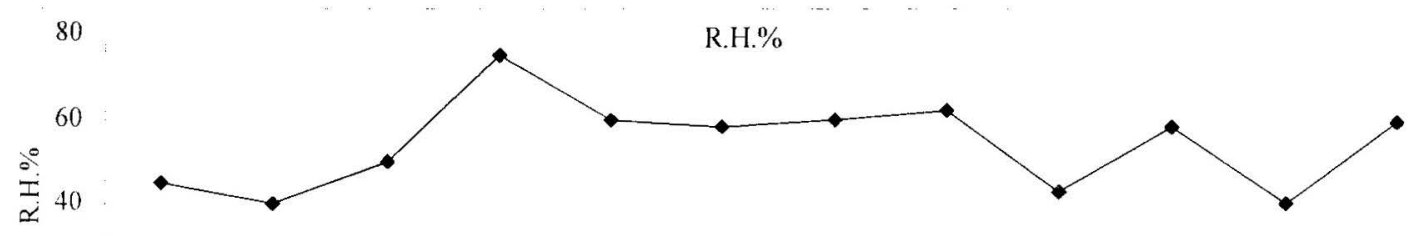

20

0

April May June July Aug. Sep. Oct. Nov. Dec. Jan. Feb. Mar.

$40 \quad$ Temprature ${ }^{\circ} \mathrm{C}$

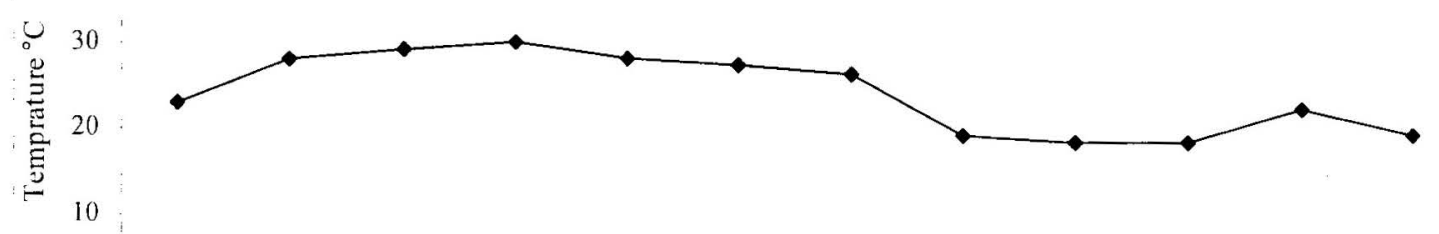

0

April May June July Aug. Sep. Oct. Nov. Dec. Jan. Feb. Mar.
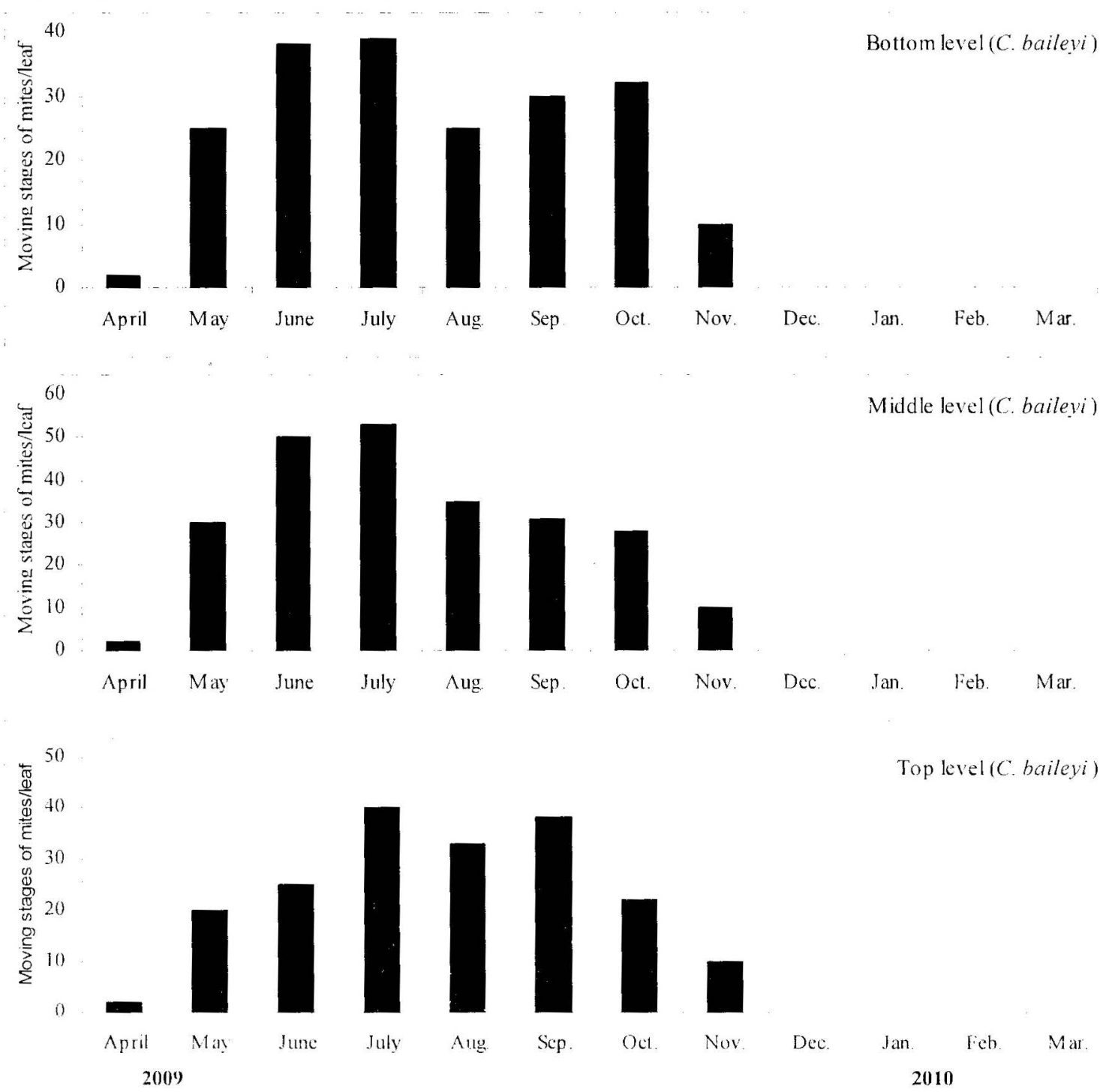

Fig. (3): Population trends of the apple rust mite, C. baileyi on Anna apple leaves in abandoned orchard from April 2009 to Marh 2010 and weather records. 
However, eriophyoid mites are unique phytophagous mites, due to having many simplification in external and internal structures and with the absence of several organs, are the result of process of adaptation of a high degree in connection with the parasitic mode of life on or inside the plant tissue.

C. baileyi was able to develop successfully from egg to adult through the entire life history at temperature between $23-35^{\circ} \mathrm{C}$ and $65 \%$ R.H. It has two nymphal stages, each followed by a resting stage, before reaching adult (Table 1). The terms used for the resting stages are those proposed by Sternlicht and Goldenberg (1971). It was concluded that the duration of egg (incubation period), first instar nymph, nymphochrysalis, second instar nymph, imagochrysalis, pre-oviposition and post-oviposition decreased as temperature increased.

The egg of $C$. baileyi is circular and translucent when first lade, then turned to light amber and opaque as a result of the embryo development. The egg is $45-51 \mu \mathrm{m}$ in diameter, and most of eggs are laid alongside the midrib or veins of leaf discs. Egg duration at $23^{\circ} \mathrm{C}$ was 1.83 times as long as that at $35^{\circ} \mathrm{C}$. The total life cycle was completed after 9.71 $\& 9.60 ; 7.59 \& 7.52$ and $5.44 \& 5.34$ days for females and males at 23,29 and $35^{\circ} \mathrm{C}$ respectively. Males developed faster. The life cycle results of Barke et al. (1972) on the peach silver mite Aculus cornutus (Banks) and Easterbrook (1979) on the apple rust mite Aculus schlechtendali (Nalepa) are almost in agreement with the aforementioned temperatures. A generation took 6.71 days at $35^{\circ} \mathrm{C}$; a decrease of $6^{\circ} \mathrm{C}$ and $12^{\circ} \mathrm{C}$ increased it by 3.95 and 7.50 days, respectively; at least $43 \%$ of the generation time was spent in the egg stage. The difference between 23 and $35^{\circ} \mathrm{C}$ of the generation time was highly significant.

The ovipositing duration decreased with increasing temperature. Female longevity at $23^{\circ} \mathrm{C}$ averaged 34.91 days, about 1.37 times as long as at $35^{\circ} \mathrm{C}$. Total fecundity gradually increased with increasing temperature.

Females deposited an average of $12.5,19.70$ and 23.09 eggs, during the oviposition period that averaged 24.08. 22.00 and 21.81 days, then survived for $6.33,4.76$ and 2.45 days at 23,29 and $35^{\circ} \mathrm{C}$, respectively (Table 1 ). The highest number of eggs per female was observed to be 23.09 at $35^{\circ} \mathrm{C}$. It could be concluded that $35^{\circ} \mathrm{C}$ is the optimum temperature for development and induced greater production of $C$. baileyi. The data obtained are in agreement with those reported by Abou-Awad et al.,(2011), who found the same effect of different temperatures on the mango rust mite, Metaculus mangiferae (Attiah). The life history took $44.62 \&$ $42.22 ; 37.42 \& 35.70$ and $30.97 \& 28.99$ days for females and males at the same previous temperatures, respectively. In general, life histories studied by Abou-Awad et al., 2000 and 2011 and Haque and Kawai, 2003 are in agreement.

Life table parameters at three different temperature degrees and $65 \%$ R.H. were constructed (Table 2). It showed that the intrinsic rate of natural increase $(\mathrm{rm})$ increased with temperature to a maximum of 0.158 at $35^{\circ} \mathrm{C}$ and decreased to 0.087 at $23^{\circ} \mathrm{C}$. The maximum rate is equal to that of the peach silver mite $A$. fockeui ( $\mathrm{rm}=0.159$, AbouAwad et al., 2010) which considered the most serious eriophyid mite pests in peach and nectarine orchards. The population of C. baileyi also multiplied 15.94 times in a generation time of 17.47 days at $35^{\circ} \mathrm{C}$, while its population only increased 8.79 times in a generation time of 25.80 days at $23^{\circ} \mathrm{C}$. Therefore, the present results reveal that $C$. baileyiis a disastrous pest to Anna apple orchards in Egypt.

\section{REFERENCES}

Abou-Awad, B. A.; Al-Azzazy, M. M. and El-Sawi, S. A. 2010. The life-history of the peach silve rmite, Aculus fockeui (Acari: Eriophyidae) in Egypt. Arch. Phytopath.and Plant Protec., 43: 384-389.

Abou-Awad, B. A; Metwally, A. M. and Al-Azzazy, M. M. 2011. Environmental management and biological aspects of two eriophyid mango mites in Egypt: Aceria mangiferae and Metaculus mangiferae. Acarologia, (In press).

Abou-Awad, B. A.; El-Sawaf, B. M.;Reda, A. S. and Abdel-Khalek, A. A. 2000. Environmental management and biological aspects of two eriophyoid fig mites in Egypt: Aceria ficus and Rhyncaphytoptus ficifoliae. Acarologia, 40: 419429.

Barke, H. E.; Davis, R. and Hunter, P. E. 1972. Studies on the peach silver mite, Aculus cornutus (Acari: Eriophyidae). J. Georgia Entomol. Soc., 7: 171-178.

Easterbrook, M. A. 1979. The life history of the eriophyid mite Aculus schlechtendali on apple in South-east England. Ann. Appl. Biol., 91: 287296.

Haque, M. M. and Kawai, A. 2003. Effect of temperature on development and reproduction of the tomato russet mite, Aculops lycopersici (Masses) (Acari: Eriophyidae). Appl. Entomol. Zool., 38: 97-101.

Hulting, F. L.; Orr, D. B. and Obrycki, J. J. 1999. A computer program for calculation and statistical comparison of intrinsic rates of increase and 
associated life table parameters. Florida Entomol., 73: 601-612.

Jeppson, L. R.; Keifer, H. H. and Baker, E. W. 1975. Mites Injurious to Economic Plants, $614 \mathrm{pp}$. Berkeley: University of California Press.

Keifer, H.H. 1938.Eriophyid studies II. Bulletin of the California Department of Agriculture, 27: 301-323.

Keifer, H. H. 1942. Eriophyid studies XII. Bulletin of the California Department of Agriculture 31: 117-129.

Manson, D. C. M. 1984. Eriophyoidea except Eriophyinae (Arachnida: Acari). Wellington; DSIR, 142 pp.

Sternlicht, M. and Goldenberg, S. 1971. Fertilization, sex ratio and postembryonic stages of the citrus bud mite, Aceria sheldoni (Ewing). Bull. Entomol. Res., 60:391-397. 